\title{
PROSES PEMBELAJARAN PPKN DENGAN MENERAPKAN MODEL INKUIRI UNTUK MENINGKATKAN MOTIVASI BELAJAR SISWA
}

\author{
${ }^{1}$ Thariq Aziz Zebua \\ ${ }^{2}$ Erwin Susanto \\ ${ }^{3}$ Lusiana Rahmatian \\ Universitas Buana Perjuangan Karawang \\ 1pk15.thariqzebua@mhs.ubpkarawang.ac.id \\ ${ }^{2}$ susanto@ubpkarawang.ac.id \\ 3lusiana.rahmatiani@ubpkarawang.ac.id
}

\begin{abstract}
ABSTRAK
Penelitian ini bertujuan untuk Mengetahui proses pembelajaran PPKn dengan menerapkan model inkuiri untuk meningkatkan motivasi belajar siswa. Penelitian ini menggunakan pendekatan kualitatif dengan metode studi deskriptif. Subjek penelitian ini adalah Siswa SMP IT Gita Wirabangsa. Teknik pengumpulan data menggunakan wawancara, observasi dan dokumentasi. Analisis data menggunakan triangulasi. Hasil penelitian menunjukkan bahwa proses penerapan model inkuiri dalam pembelajaran PPKn untuk meningkatkan motivasi belajar siswa menggambarkan suasana kelas cukup kondusif, meski masih saja ada siswa yang pasif, mungkin dengan berjalannya waktu dan siswa terbiasa. Dengan diterapkan model ini siswa di kelas menjadi aktif, nampak bahwa dalam prosesnya pembelajaran PPKn tersebut, siswa sangat aktif ketika berjalannya diskusi, dan suasana kelas menjadi tidak membosankan, tentu dengan model ini, siswa dituntut untuk berpikir kritis, dan siswa pun menjadi tidak malu untuk bertukar pikiran dengan teman sebayanya.
\end{abstract}

\section{Kata Kunci: Proses Pembelajaran PPKn, Model Pembelajaran Inkuiri}

\begin{abstract}
This study aims to determine the civic learning process by applying an inquiry model to increase student motivation. This research uses a qualitative approach with descriptive study methods. The subjects of this study were IT Gita Wirabangs a Junior Highschool students. Data collection techniques using interviews, observation and documentation. Data analysis using triangulation. The results showed that the process of applying the inquiry model in civic learning to increase student learning motivation described the class atmosphere as quite conducive, although there were still students who were passive, maybe with time and students got used to it. By applying this model students in the class become active, it appears that in the PPKn learning process, students are very active when the discussion is going on, and the class atmosphere is not boring, of course with this model, students are required to think critically, and students are not ashamed to exchange ideas with peers.
\end{abstract}

Keywords: Civic Learning Process, Inquiry Learning Model 


\section{PENDAHULUAN}

Proses pembelajaran harus menggunakan model, strategi dan media pembelajaran yang sesuai supaya menumbuhkan minat belajar siswa yang tinggi. Di dalam proses belajar mengajar, guru harus memiliki strategi dalam pembelajaran, agar siswa dapat belajar secara efektif dan efisien, mencapai pada tujuan yang diharapkan, salah satu langkah untuk memiliki strategi itu ialah harus menguasai teknik-teknik penyajian, atau disebut model mengajar.

Model pembelajaran mempunyai peran yang sangat penting dalam kegiatan belajar mengajar, karena penggunaan model pembelajaran merupakan bagian yang harus mendapat perhatian guru dalam setiap kegiatan pembelajaran. Model yang digunakan untuk memecahkan suatu masalah yang dihadapi ataupun untuk menjawab suatu pertanyaan yang berbeda, dengan model yang digunakan untuk tujuan agar siswa mampu berpikir dan mengemukakan pendapatnya sendiri.

Guru harus lebih dinamis dan kreatif dalam mengembangkan proses pembelajaran bagi peserta didik. Dalam pembelajaran guru harus senantiasa melakukan berbagai peningkatan pembelajaran dan mengembangkan model pembelajaran yang tepat sesuai pada mata pelajarannya.

Di sekolah, sebagai pendidik atau pengajar, guru merupakan salah satu faktor penentu keberhasilan setiap upaya pendidikan. Sebagai pengajar dan pendidik guru harus memiliki sekolah kompetensi atau kemampuan yang sesuai dalam pembelajaran untuk meningkatkan kualitas pembelajaran.

\section{METODE PENELITIAN}

Pendekatan dalam penelitian ini menggunakan pendekatan kualitatif dengan metode studi deskriptif. Subjek dalam penelitian ini adalah 3 siswa, 1 guru mata pelajaran, dan 1 guru sebagai expert judgement SMP IT Gita Wirabangsa. Teknik pengumpulan data menggunakan observasi, wawancara dan dokumentasi. Keabsahan data menggunakan triangulasi sumber. Teknik analisis data dilakukan dengan tiga alur tahap kegiatan yaitu, reduksi data, penyajian data kemudian penarikan kesimpulan.

\section{HASIL DAN PEMBAHASAN}

\section{Proses pembelajaran PPKn dengan menerapkan model inkuiri untuk meningkatkan motivasi belajar siswa}

Untuk mendapat informasi mengenai proses pembelajaran model inkuiri dalam pembelajaran PPKn untuk meningkatkan motivasi belajar siswa, peneliti menelaah wawancara hasilnya adalah sebagai berikut :

Menurut FP, peran guru dalam menerapkan model pembelajaran dengan menggunakan model inkuiri yaitu membimbing jalannya kegiatan belajar mengajar dengan menggunakan model inkuiri. Adapun suasana kelas saat kegiatan belajar mengajar dengan menggunakan model ini, cukup kondusif tapi ada saja salah satu siswa maupun siswi yang tidak memperhatikan saat guru memaparkan materi. Adapun tahapan dalam menerapkan model ini yaitu dengan memaparkan materi, membagi kelompok.

Menurut YA, saat penerapan model inkuiri dalam pembelajaran PPKn untuk meningkatkan motivasi belajar siswa peran guru sangatlah bagus, akan tetapi jika penerapan model inkuiri dalam pembelajaran PPKn ini tidak bisa semenamena di tinggalkan oleh guru karena disini guru sangat berperan dalam membagi kelompok. Meski dalam hal ini guru sudah tidak lagi menjadi teacher center, namun ketika berjalannya kegiatan diskusi guru sangat berperan sebagai motivator. Adapun suasana kegiatan belajar mengajar di kelas 
cukup kondusif dan ramai, namun ramai disini merupakan ramai berkualitas (siswa aktif dan sangat berperan dalam berjalannya diskusi).

Menurut RI, situasi di kelas saat guru menerapkan model inkuiri sangat ramai, dalam arti banyak diskusi mengenai materi yang sudah di sampaikan oleh guru pada materi sebelumnya, teringat lagi saat pembahasan ketika berjalannya diskusi, jadi materi sebelumnya dengan materi yang sedang dibahas saling berkesinambungan. Adapun pendapat lain dari ENA saat guru menerapkan model inkuiri sangat bermotivasi dalam belajar, karena siswa di tuntut akan berfikir secara kritis dan bertukar pikiran dengan teman, serta saat guru menerapkan model inkuiri, tidaklah membosankan ketika belajar, tetapi demikian masih ada juga yang tidak perduli akan materi yang sudah di sampaikan oleh guru. Sedangkan pendapat lain dari AS, bahwa saat guru menerapkan model inkuiri, siswa banyak yang aktif dalam berdiskusi dan bisa bertukar pikiran menerima pendapat-pendapat teman dengan materi yang di sampaikan. Berkaitan dengan proses pembelajaran pun kami merasa sangat termotivasi, terutama bagi ia yang memiliki karakter tidak percaya diri sejak lama, karena pembelajaran dengan model ini kami dituntut untuk aktif dalam pembelajaran, maka yang tadinya kelas sangat pasif, hanya ada beberapa saja yang aktif, sekarang dengan model inkuiri yang diterapkan guru ini suasana belajar dikelas menjadi sangat menyenangkan.

Tabel 1 Triangulasi Sumber

\begin{tabular}{ccc}
\hline \multicolumn{3}{c}{ Triangulasi Sumber } \\
\hline Guru & Expert & Siswa \\
& Judgmen & \\
& $\boldsymbol{t}$ & \\
\hline Dilihat & Dilihat & Dilihat dari \\
dari & dari & pandangan \\
\hline
\end{tabular}

\begin{tabular}{|c|c|c|}
\hline pandangan & pandanga & RI, ENA, \\
\hline $\begin{array}{l}\mathrm{FP} \text {, dalam } \\
\text { prosesnya }\end{array}$ & $\begin{array}{l}\text { n YA, } \\
\text { ketika }\end{array}$ & $\begin{array}{l}\text { dan } \mathrm{SA} \\
\text { ketika proses }\end{array}$ \\
\hline ketika guru & proses & kegiatan \\
\hline menerapka & kegiatan & belajar \\
\hline $\mathrm{n}$ model ini & belajar & mengajar \\
\hline suasana & mengajar & berlangsung, \\
\hline kelas saat & berlangsu & siswa \\
\hline kegiatan & ng & tuntut \\
\hline belajar & suasana & berfikir \\
\hline mengajar & kegiatan & secara kritis \\
\hline dengan & belajar & dan bertukar \\
\hline mengguna & mengajar & pikiran \\
\hline kan model & di kelas & dengan \\
\hline ini, cukup & ramai, & teman, serta \\
\hline kondusif & namun & saat guru \\
\hline tapi ada & ramai & menerapkan \\
\hline saja salah & disini & model \\
\hline satu siswa & merupak & inkuiri, \\
\hline maupun & an ramai & tidaklah \\
\hline siswi yang & berkualit & membosanka \\
\hline tidak & as (siswa & ketika \\
\hline memperha & aktif dan & belajar, \\
\hline tikan saat & sangat & tetapi \\
\hline guru & berperan & demikian \\
\hline memapark & dalam & masih \\
\hline an materi. & berjalann & juga \\
\hline & ya & tidak perduli \\
\hline & diskusi). & akan materi \\
\hline & & yang sudah \\
\hline
\end{tabular}


di sampaikan

oleh guru. disimpulkan pembahasan hasil triangulasi sumber dalam proses ketika menerapkan model inkuiri dalam pembelajaran PPKn untuk meningkatkan motivasi belajar siswa ialah suasana kelas cukup kondusif, meski masih saja ada siswa yang pasif, mungkin dengan berjalannya waktu dan siswa terbiasa, guru mengharapkan setidaknya $90 \%$ dengan diterapkan model ini siswa di kelas menjadi aktif, ketika proses dalam pembelajarannya siswa sangat berperan ketika berjalnnya diskusi, dan suasana kelas menjadi tidak membosankan, tentu dengan model ini, siswa dituntut untuk berpikir kritis, dan siswa pun menjadi tidak malu untuk bertukar pikiran dengan teman sebayanya, jadi dengan di terapkannya model ini ketika proses pembelajaran, dirasa cukup baik.

Pembelajaran menurut Winkel (1991) adalah "seperangkat tindakan yang dirancang untuk mendukung proses belajar siswa, dengan memperhitungkan kejadiankejadian ekstrim yang berperanan terhadap rangkaian kejadian-kejadian yang intern yang berlangsung dialami siswa. Jadi, berdasarkan pendapat Winkel pembelajaran berawal dari kejadian-kejadian ekstrim yang terjadi dan dialami langsung oleh siswa itu sendiri".

Adapun pengertian model inkuiri menurut Mulyasa (2007), adalah "model yang mampu mengiring peserta didik untuk menyadari apa yang telah didapatkan selama belajar".
Menurut Lahadisi (2014: 88)

"Inkuiri berasal dari bahasa inggris "inquiri" secara harfiah berarti pertanyaan atau pemerikasaan, penyelidikan, maka di tegaskan bahwa inkuiri adalah the process of infestigating a problem (proses penyelidikan masalah) sedangkan secara terminologi inkuiri berarti proses berfikir kritis dan analisis untuk mencari dan menemukan sendiri jawaban dari satu masalah yang dipertanyakan".

Dengan kata lain inkuiri berkaitan dengan aktivitas dan keterampilan aktif yang fokus pada pencarian pengetahuan atau pengalaman untuk memuaskan rasa ingin tahu". Jadi, bisa dikatakan bahwa inkuiri merupakan proses penyelidikan masalah yang ada di lingkungan sekitar serta harus dianalisis secara kritis dan berkelompok. Maka bisa dikatakan inkuiri ialah yang berkaitan dengan aktivitas juga keterampilan yang berfokus pada pencarian pengetahuan serta pengalaman.

Berkaitan dengan motivasi
belajar, maka peneliti mengambil
definisi menurut Setyowati (2007) yang
juga model inkuiri ini merupakan
"kebutuhan untuk mengembangkan
kemampuan diri secara optimum,
sehingga mampu berbuat yang lebih
baik, berprestasi dan kreatif".

\section{KESIMPULAN DAN IMPLIKASI}

Dengan di terapkannya model inkuiri dalam pembelajaran PPKn untuk meningkatkan motivasi belajar siswa ini, ketika proses penerapannya tentu sangatlah bagus, akan tetapi jika penerapan model inkuiri dalam pembelajaran PPKn ini tidak bisa semenamena di tinggalkan oleh guru karena disini guru sangat berperan dalam membagi kelompok. Meski dalam hal ini guru sudah 
tidak lagi menjadi teacher center, namun dengan diterapkannya model inkuiri ini, ketika berjalannya kegiatan diskusi guru sangat berperan sebagai motivator, sehingga guru harus standby di dalam kelas dan jika di tinggalkan kelas kemungkinan akan kacau, sehingga proses diskusi tidak berjalan dengan baik.

\section{DAFTAR PUSTAKA}

Darmawati, J. (2013). Pengaruh Motivasi Belajar Dan Gaya Belajar Terhadap Prestasi Belajar Ekonomi Siswa SMA Negeri Di Kota Tuban. Tuban:

Pendidikan Ekonomi. Vol 1. Hal 80.

Emda, A. (2017). Kedudukan Motivasi Belajar Siswa Dalam Pembelajaran. Banda Aceh: Pendidikan Tarbiyah. Vol 5. Hal 1.

Erwin Susanto. (2015). Pengaruh Pembelajaran, Habituasi dan Ekstrakurikuler Terhadap Pengembangan Civic Disposition Siswa SMA Negeri se-Kota Bandar Lampung. Bandung: Pendidikan Kewarganegaraan.

Fitri, Saparayuningsih \& Agustriana. (2013). Perencanaan Pembelajaran Kurikulum 2013 Pendidikan Anak Usia Dini. Bengkulu: PAUD. Vol 2. Hal 3.

Heriawan, A., Darmajari \& Senjaya, A. (2007). Metodologi Pembelajaran. Banten: CV Iskandar.

Inah Nur Ety. (2015). Peran Komunikasi Dalam Interaksi Guru Dan Siswa.

Kendari: Fakultas Tarbiyah. Vol 8. Hal 152 Isjoni, H. (2013). Pembelajaran Kooperatif. Yogyakarta: Pustaka Belajar

Kaelan. (2013). Pendidikan Pancasila. Yogyakarta: Paradigma

Kosasih. (2016). Strategi Belajar dan Pembelajaran. Bandung: Yrama Widya
Lahadisi. (2014). Inkuiri Sebuah Strategi Menuju Pembelajaran Bermakna.

Kendari: Tarbiyah. Vol 7. Hal 88-91.

Nasution, K. M. (2017). Penggunaan Metode Pembelajaran Dalam Peningkatan Hasil Belajar Siswa. Serang Banten: Pendidikan Ilmu Tarbiyah. Vol 11. Hal 15.

Rahmatiani Lusiana. (2012). Pengaruh Pembelajaran Kooperatif Metode Student Team Achievement Division (STAD) dengan Peningkatan Pemahaman Siswa pada Mata Pelajaran PKn. Cimahi: PPKn

Ristawati. (2017). Pengaruh Media Pembelajaran Terhadap Motivasi Belajar Siswa. Makassar: Pend. Ilmu Sosial. Vol 2. Hal 158-159

Sugiyono. (2017). Metodologi Penelitian. Bandung: Alfabeta

Siregar dan Nara. (2017). Teori Belajar dan Pembelajaran. Bogor: Ghalia Indonesia

Silvia. (2013). Implementasi Model Pembelajaran Example Non Example dalam Upaya Meningkatkan Motivasi Belajar Siswa pada Pembelajaran Pendidikan Kewarganegaraan. Bandung: Pendidikan Kewarganegaraan

Setyowati. (2007). Pengaruh Motivasi Belajar Terhadap Hasil Belajar. Semarang: Pend. Administrasi. Vol 5. Hal 14-16

Sumantri Bambang. (2014). Peningkatan Kualitas Pembelajaran Pkn Melalui Model Pembelajaran Kooperatif Tipe Teams Game Tournamen (Tgt) Pada Siswa Kelas II Sd Negeri Pelem 2 Ngawi. Ngawi: PKn. Vol 13. Hal 24

Suprihatin Siti. (2015). Upaya Guru Dalam Meningkatkan Motivasi Belajar Siswa. Metro: Pendidikan Ekonomi.Vol 3. Hal 73-76. 
Wahyuni Arie. (2017). Analisis Hambatan Belajar Mahasiswa Pada Mata Kuliah Kalkulus Dasar. Semarang: Pendidikan Matematika. Vol 1. Hal 6.

W.S.Winkel. (1991). Psikologi Pengajaran. Jakarta: PAU-PPAI Dirjen Dikti Depdikbud.

https://hildhaauliamaretha.wordpress.com/ 2017/09/20/pendidikan-

kewarganegaraan/ [diakses pada 10 Mei 2018 Pukul 16:00]

https://dosenmuslim.com/pendidikan/indik ator-indikator-motivasi-belajar/ [diakses pada 20 Desember 2018 Pukul 20:32] 